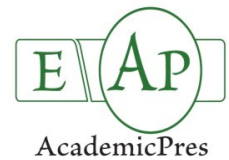

\title{
Growth of Scots Pine and Silver Birch Seedlings on Different Nursery Container Media
}

\author{
Tekin MEMISOGLU ${ }^{1}$, Fahrettin TILKI ${ }^{2 *}$ \\ ${ }^{I}$ Eastern Anatolia Forestry Research Institute, 25240 Erzurum, Turkey \\ ${ }^{2}$ Artvin Coruh University, Faculty of Forestry, 08000 Artvin, Turkey; ftilki@artvin.edu.tr ("correspondingauthor)
}

\begin{abstract}
Peat has been the most common growing medium in tree nurseries, either alone or as a component of growing media mixes. However, as a result of increasing costs and decreasing amount of peat, seedling-growers are seeking more local growing medium components. In this study, container seedlings of Scots pine (Pinus sylvestris L.) and silver birch (Betula pendula Roth) were grown in pure peat and peat mixtures containing perlite and zeolite. Physical parameters (height, shoot diameter, root dry weight, shoot dry weight, total dry weight) were measured along with several morphological parameters (sturdiness quotient, height/diameter, shoot/root ratio). The zeolite additive in peat changed some media properties, and significant relation was established between some morphological attributes of seedlings and some medium properties in both species. On average, the seedlings grew best in pure peat, but zeolite additions to peat did not affect some morphological parameters negatively. The results suggest that zeolite has potential to be used as a component of peat based growing medium mixtures, and addition of zeolite to peat container medium in proportions of $10 \%$ by volume in Scots pine and up to $20 \%$ in silver birch was shown to be a feasible material for growing Scots pine and silver birch seedlings.
\end{abstract}

Keywords: growth medium, morphological attributes, nursery, seedling quality, zeolite

\section{Introduction}

Competing vegetation, transplant shock, low seedling quality or lack of site preparation can reduce outplanting success (Ward et al., 2000; Apholo and Rikala, 2003; Jacobs et al., 2004 and 2012; Wilson and Jacobs, 2006; Pinto et al., 2011; Tsakaldimi et al., 2013). Thus, field establishment may be improved through nursery treatments that ensure high quality seedlings and promote the development of a well structured root system (Tsakaldimi et al., 2009). Determination of the morphological and physiological attributes of seedlings that can be quantitatively correlated with improved field performance of planted seedlings and thus, can be successfully used for predicting the early plantation success, should be of high priority in forest practice (Duryea, 1985; Mattsson, 1997; Wilson and Jacobs, 2006; Aytas and Tilki, 2007; Tsakaldimi et al., 2013).

Many parameters used to measure seedling quality in relation to field survival and productivity (Dey and Parker, 1997; Stone et al., 2003; Li et al., 2011; Tsakaldimi et al., 2013). Most of these are based on morphological characteristics, which are relatively simple to measure (Thompson, 1985; Pinto et al., 2011; Tsakaladami et al., 2013) and well correlated with field success (Dierauf and Garner, 1996; Dey and Parker, 1997; Apholo and Rikala, 2003; Semerci, 2005). Seedling diameter and height are easy to measure, and they have an important role in field performance (Thompson, 1985; Mexal and Landis, 1990; South et al., 2005; Tsakaladami et al., 2013). Total dry weight, sturdiness quotient, the Dickson quality index and shoot/root ratio are also common parameters used in the quality classification (Thompson, 1985; Jaenicke, 1999; Apholo and Rikala, 2003; Manas et al., 2009; Tsakaldimi et al., 2013).

Container media is an important determinant of seedling quality, and peat has been the most common growing medium for growing seedlings (Langerud and Sandvik, 1987; Bunt, 1988; Landis et al., 1990; Schmilewski, 1992). However, as a result of increasing costs, decreasing amount of peat, and the social pressure to reuse the waste resulting from human or industrial activities, local growing medium components (sewage sludge, pine bark, sawmill residues, perlite and numerous other substitutes in different proportions) were studied in using growing experiments in many countries and also in Turkey (Landis et al., 1990; Chong and Lumis, 2002; Aldrete and Mexal, 2005; Ayan and Tilki, 2007; Manas et al., 2009; Heiskanen, 2013). The properties of peat-based media can influence water and air availability and plant growth (Langerud and Sandvik, 1987; Heiskanen, 1993, 1997).

Zeolites, a naturally occurring mineral group consisting about of 50 mineral types, draw attention as a good 
growing medium substrate for a long period due to its good physical and chemical characteristics (Markovich et al., 1995). They have a rigid three-dimensional crystal structure with voids and channels of molecular size and high cation exchange capacity (CEC) arising from substitution of $\mathrm{Al}$ for $\mathrm{Si}$ in the silicon oxide tetrahedral units that constitute the mineral structure (Ayan, 2002; Pickering et al., 2002). Zeolite has many good features that make it very attractive for nursery use as a growing medium compared to other growing media types such as perlite, pumice and river sand (Koksaldi, 1999). Although Turkey has very rich zeolite potential, there is a lack of information on the possibility of commercial use of zeolite as a growing media in seedling production.

The aim of the present study was to determine how different growing media based on peat with zeolite affect seedling survival and attributes in nursery. For this purpose, Scots pine and silver birch, important tree species in Eastern Turkey due to their ecological and economic value, have been selected.

\section{Materials and methods}

\section{Seedling production}

One-year-old Scots pine and silver birch seedlings were grown in containers following normal practice for Turkish nurseries at the nursery of the East Anatolia Forest Research Institute at Erzurum (1750 m asl), Turkey. Seeds of Scots pine from Kars-Sarikamis origin were sown to plastic enso container trays (Enso-Finland Model Type) ( 9 x 5 cells of $220 \mathrm{~cm}^{3}$ each) on April 21, 2008, and seeds of silver birch from Erzurum origin were sown to plastic enso container trays on June 14, 2008 in greenhouse. The laboratory germination capacity of the Scots pine and silver birch seed lots was $97 \%$ and $90 \%$ at 21 days, respectively.

Seedlings were kept in greenhouse for two months after sowing. Later, they transferred into a shaded area for one month for acclimatization before letting them outdoor conditions. Seedlings were kept in outdoor conditions until they got ready for planting. Mixtures of Finland peat (FP), zeolite $(\mathrm{Z})$ and perlite $(\mathrm{P})$ were used as growing media in the trays. Finland peat was used as main additive material in pots and was classified as $\mathrm{H} 1-\mathrm{H} 3$ quality class peat according to Von Post scale, particle size was less than 2 $\mathrm{mm}$. Balikesir-Bigadic (Turkey) originated clinoptilolite natural zeolite, clinodor-agro, particle size was 1-3 mm was also used as a growing medium. Six different volume combinations of these three different potting media with and without zeolite were established and used as arowing

Tab. 1. Composition (\% by volume) of the growth media used in the study

\begin{tabular}{cccc}
\hline Growing medium & Peat (\%) & Perlite (\%) & Zeolite (\%) \\
\hline FP100 & 100 & 0 & 0 \\
FP70P20Z10 & 70 & 20 & 10 \\
FP70P10Z20 & 70 & 10 & 20 \\
FP90Z10 & 90 & 0 & 10 \\
FP80+Z20 & 80 & 0 & 20 \\
FP80P10Z10 & 80 & 10 & 10 \\
\hline
\end{tabular}

FP: Finland peat; P: Perlite; Z: Zeolite medium. The proportions of the components hand-mixed into the peat were determined by volume (Tab. 1).

Daily watering was done with sprinklers. During the growing season in the nursery the seedlings were fertigated (fertilized with the irrigation water) with Superex after analyzing soil for EC and $\mathrm{pH}$ regularly (Tabs. 2, 3) (Richard and McDonald, 1979).

Tab. 2. Fertilizers application for Scots pine

\begin{tabular}{lcc}
\hline $\begin{array}{c}\text { Fertilizer chemical } \\
\text { content }\end{array}$ & $\begin{array}{c}\text { Amount } \\
\left(\mathrm{g} / \mathrm{m}^{2}\right)\end{array}$ & Application time \\
\hline $\begin{array}{l}\text { N } 13 \%+\text { P } 40 \%+\mathrm{K} \\
13 \%+\text { micro elements }\end{array}$ & 43 & 20 May - 01 June \\
$\begin{array}{l}\text { N 20\%+ P 20 } \%+\mathrm{K} \\
20 \%+\text { micro elements }\end{array}$ & 46 & 02 June - 30 August \\
$\begin{array}{l}\text { N 19\%+ P 6 } \%+\mathrm{K} \\
20 \%+\text { micro elements }\end{array}$ & 65 & $\begin{array}{c}\text { 01 September - 30 } \\
\text { September }\end{array}$ \\
$\begin{array}{l}\text { N 0 } \%+\text { P 25 } \%+\mathrm{K} \\
36 \%+\text { micro elements }\end{array}$ & 40 & $\begin{array}{c}\text { 30 September }- \text { until the } \\
\text { end of the vegetation season }\end{array}$ \\
\hline
\end{tabular}

Tab. 3. Fertilizers application for silver birch

\begin{tabular}{|c|c|c|}
\hline $\begin{array}{c}\text { Fertilizer chemical } \\
\text { content }\end{array}$ & $\begin{array}{c}\text { Amount } \\
\left(\mathrm{g} / \mathrm{m}^{2}\right)\end{array}$ & Application time \\
\hline $\begin{array}{l}\mathrm{N} 13 \%+\mathrm{P} 40 \%+\mathrm{K} \\
13 \%+\text { micro elements }\end{array}$ & 15 & 10 August -30 August \\
\hline $\begin{array}{l}\mathrm{N} 17 \%+\mathrm{P} 9 \%+\mathrm{K} \\
33 \%+\text { micro elements }\end{array}$ & 70 & 30 August - 30 September \\
\hline $\begin{array}{l}\mathrm{N} 0 \%+\mathrm{P} 25 \%+\mathrm{K} \\
36 \%+\text { micro elements }\end{array}$ & 50 & $\begin{array}{l}30 \text { September - until the end } \\
\text { of the vegetation season }\end{array}$ \\
\hline
\end{tabular}

\section{Physical and chemical characteristics of the media}

During growing season soil $\mathrm{pH}$ and $\mathrm{EC}$ were measured. Before seed sowing, growing media samples were analysed for their physical and chemical properties such as bulk density, water holding capacity, specific gravity, porosity and air capacity.

Organic matter content was determined by the Walkley-Black method (Nelson and Sommers, 1996), $\mathrm{pH}$ was measured with a combination glass-electrode in $\mathrm{H}_{2} \mathrm{O}$ (soil-solution ratio 1:2.5), and cation exchange capacity was calculated by the sum of cations determined by the $\mathrm{NH}_{4} \mathrm{OAc}$ method (Kalra and Maynard, 1991).

Phosphorus was determined according to Brayl (Dilute acid-fluoride) procedure (Kalra and Maynard, 1991). Exchangeable cations and micronutrient cations were determined by atomic absorption spectrophotometry according to Kacar (1996). Electrical conductivity was determined following the procedure described by Kalra and Maynard (1991). The total nitrogen was analysed by the micro Kjeldahl technique (Kalra and Maynard, 1991).

The bulk density (Db) was determined by the core method (Grossman and Reinch, 2002) and the particle density (Dp) was determined by the pycnometer method. The total porosity (TP) was estimated as (Dp-Db) $\mathrm{Dp}^{-1}$, where $\mathrm{Db}$ is the bulk density (Heiskanen, 1993), obtained by using the following equation: $\mathrm{St}=[1-$ (bulk density/particle density] (Flint and Flint, 2002). Air content was estimated based on the formula: Air content $(\%)=$ Porosity (\%)-Water holding capacity (\%). 
567

Seedling measurements

In each species, 45 seedlings per treatment were sampled at random. Shoots height, root collar diameter, and dry weight of shoots and roots were measured at the end of first vegetation period.

Dry weight was measured after drying for $24 \mathrm{~h}$ at $105^{\circ} \mathrm{C}$.

The sturdiness quotient $=\mathrm{H} / \mathrm{D}[$ height $(\mathrm{cm}) /$ diameter $(\mathrm{mm})]$.

The Dickson's Quality Index (DQI) was also calculated as follows (Bayala et al., 2009): DQI=seedling dry weight (g) $x\left[\left(\right.\right.$ height $(\mathrm{cm}) \times$ root collar diameter $\left.(\mathrm{mm})^{-1}\right)+($ shoot dry weight $(\mathrm{g})$ x root dry weight $\left.\left.(\mathrm{g})^{-1}\right)\right]^{-1}$.

\section{Experimental design and data analysis}

Experiment was arranged in a completely randomized block design with three replications for each treatment. Totals of 6 treatments were randomly assigned into each block. 45 seedlings per treatment in each species were sampled in each sampling time. To test the significance of differences the data of seedling attributes were analysed with ANOVA in a randomized block design (SPSS software, SPSS Inc). Variables were tested for normality and homogeneity of variances and transformations were made when necessary to meet the underlying statistical assumptions of ANOVA. Duncan's New Multiple Range Test procedure was used to compare mean values (for $\mathrm{p}<0.05)$.

Tab. 4. $\mathrm{pH}$ and EC of the growing media of Scots pine

\begin{tabular}{ccccccc}
\hline Growing medium & Date & $\mathrm{pH}$ & $\mathrm{Ec}(\mathrm{mS} / \mathrm{cm})$ & Date & $\mathrm{pH}$ & $\mathrm{Ec}(\mathrm{mS} / \mathrm{cm})$ \\
\hline FP 100 & 14.05 .2008 & 5.1 & 1.3 & 10.07 .2008 & 5.9 & 1.2 \\
FP70P20Z10 & 14.05 .2008 & 5.0 & 0.9 & 10.07 .2008 & 5.7 & 1.0 \\
FP70P10Z20 & 14.05 .2008 & 5.2 & 0.9 & 10.07 .2008 & 5.9 & 0.8 \\
FP90Z10 & 14.05 .2008 & 5.2 & 0.9 & 10.07 .2008 & 5.7 & 0.7 \\
FP80+Z20 & 14.05 .2008 & 5.0 & 0.9 & 10.07 .2008 & 5.8 & 0.8 \\
FP80P10Z10 & 14.05 .2008 & 5.2 & 1.0 & 10.07 .2008 & 5.7 & 0.9 \\
\hline
\end{tabular}

Tab. 5. pH and EC of the growing media of silver birch

\begin{tabular}{ccccccc}
\hline Growing medium & Date & $\mathrm{pH}$ & $\mathrm{Ec}(\mathrm{mS} / \mathrm{cm})$ & Date & $\mathrm{pH}$ & $\mathrm{Ec}(\mathrm{mS} / \mathrm{cm})$ \\
\hline FP 100 & 10.08 .2008 & 5.6 & 1.2 & 18.09 .2008 & 5.3 & 1.3 \\
FP70P20Z10 & 10.08 .2008 & 5.2 & 1.3 & 18.09 .2008 & 6.0 & 1.0 \\
FP70P10Z20 & 10.08 .2008 & 5.6 & 0.9 & 18.09 .2008 & 5.2 & 1.5 \\
FP90Z10 & 10.08 .2008 & 5.3 & 1.4 & 18.09 .2008 & 5.7 & 1.1 \\
FP80+Z20 & 10.08 .2008 & 5.9 & 1.1 & 18.09 .2008 & 6.2 & 1.4 \\
FP80P10Z10 & 10.08 .2008 & 5.7 & 1.2 & 18.09 .2008 & 5.8 & 1.2 \\
\hline
\end{tabular}

Tab. 6. Soil analysis for the growing media mixtures

\begin{tabular}{|c|c|c|c|c|c|c|}
\hline Soil analysis & FP100 & FP70P20Z10 & FP70P10Z20 & FP90Z10 & FP80Z20 & FP80P10Z10 \\
\hline $\mathrm{pH}$ & 5.27 & 5.23 & 5.13 & 5.07 & 5.16 & 5.15 \\
\hline $\mathrm{Ec}(\mathrm{mS} / \mathrm{cm})$ & 0.42 & 0.31 & 0.28 & 0.32 & 0.31 & 0.31 \\
\hline Water holding cap. (vol.\%) & 76 & 61 & 66 & 69 & 64 & 67 \\
\hline Air cap. (vol.\%) & 16.40 & 22.58 & 14.20 & 17.61 & 18.33 & 16.37 \\
\hline Total Por. (vol.\%) & 92.40 & 84.58 & 80.20 & 86.61 & 82.33 & 83.37 \\
\hline CEC (me/100g) & 127.6 & 93.7 & 87.5 & 113.5 & 86.5 & 107.5 \\
\hline $\mathrm{C} / \mathrm{N}$ & 11.57 & 11.59 & 11.60 & 11.59 & 11.58 & 11.61 \\
\hline O.M. \% & 67.09 & 42.66 & 36.91 & 53.28 & 43.61 & 42.26 \\
\hline Na ppm & 110 & 405 & 250 & 150 & 165 & 280 \\
\hline $\mathrm{K}$ ppm & 1410 & 1081 & 2115 & 1269 & 2162 & 1363 \\
\hline $\mathrm{Mg} \mathrm{ppm}$ & 436 & 776 & 844 & 745 & 792 & 885 \\
\hline P ppm & 186 & 211 & 190 & 190 & 160 & 182 \\
\hline B ppm & 5.45 & 6.00 & 5.75 & 6.70 & 7.25 & 6.20 \\
\hline C \% & 22.10 & 20.75 & 20.30 & 21.55 & 20.95 & 20.78 \\
\hline $\mathrm{N} \%$ & 1.91 & 1.79 & 1.75 & 1.86 & 1.81 & 1.79 \\
\hline Zn ppm & 10 & 5 & 7 & 10 & 7 & 8 \\
\hline $\mathrm{Cu}$ ppm & 6.30 & 5.40 & 7.20 & 8.40 & 9.60 & 7.80 \\
\hline $\mathrm{Al}$ ppm & 355 & 3649 & 5439 & 4033 & 5115 & 5182 \\
\hline Ca ppm & 2987 & 3731 & 4065 & 4037 & 3662 & 3930 \\
\hline Fe ppm & 47 & 76 & 97 & 79 & 79 & 83 \\
\hline Mn ppm & 54 & 15 & 19 & 28 & 16 & 17 \\
\hline $\mathrm{Pb} \mathrm{ppm}$ & 34 & 14 & 14 & 25 & 13 & 14 \\
\hline S ppm & 473 & 137 & 102 & 272 & 120 & 159 \\
\hline
\end{tabular}




\section{Results and discussions}

The $\mathrm{pH}$ increased while EC was relatively uniform during growing season in Scots pine growing media. These two parameters were uniform in silver birch growing media during growing season (Tabs. 4, 5).

The main soil characteristics of the growing mixtures studied were shown in Tab. 6. Organic matter content decreased with the zeolit of the mix. The water holding capacity of the mixes and total porosity decreased slightly with the zeolit content. The chemical properties varied among the mixes. The $\mathrm{pH}$ was 5.07-5.27 and was high (at $5.27)$ in pure peat, as was electrical conductivity $(0,42 \mathrm{mS}$ $\mathrm{cm}^{-1}$ ) and CEC (127.6 mg/100 g). Na, Mg, Al, B, Cu, Ca and Fe increased with the zeolit content of the mixes.

The germination capacity of the Scots pine and the silver birch seed lots was $95 \%$ and $85 \%$ at 60 days from sowing, respectively. Scots pine and silver birch had very low mortality. Seedling emergence in seedling production is affected by many factors, and growing media is one of them (Aldrete and Mexal, 2005; Manas et al., 2009). In this study there were no differences in mortality among media in each species although some chemical properties of growing media with zeolite changed. Although the zeolite and/or perlit additive in peat changed the some properties of the medium, the lower Ec, water holding capacity, organic matter, Fe, $\mathrm{Mn}, \mathrm{Pb}, \mathrm{S}$, and the higher $\mathrm{Mg}, \mathrm{Al}, \mathrm{Ca}$ in zeolite additive growing media had no distinctive effect on seedling emergence and survival.

There were no significant differences between the growing media in the diameter growth of Scots pine. But the other parameters were significantly affected by the growth medium $(\mathrm{p}<0.05)(\mathrm{Tab} .7)$. Additions of zeolite and/or perlite to peat medium were found to affect other seedling morphological parameters.
The tallest Scots pine seedlings were grown in peat, and the seedlings grown in peat, reached a stem length of 13.52 $\mathrm{cm}$. No treatment differences in seedling height were obtained for those grown in pure peat, FP70P20Z10 and FP90Z10. The lowest height growth $(11.86 \mathrm{~cm})$ was obtained in FP80Z20. The highest seedling root dry weight values were recorded in pure peat and the lowest in FP70P20Z10 and FP70P10Z20. Althought shoot dry weight was the highest in pure peat, it did not differ significantly between the seedlings grown in P100, FP70P20Z10, FP80P10Z10, FP90Z10. Seedling grown in media containing $20 \%$ perlite had the highest S/R. The growing media containing Z20 decreased the shoot dry weight and SQ. In all the substrates, the lowest DQI was recorded in FP70P20Z10, and no treatment differences in DQI were obtained for those grown in other mediums.

All morphological parameters of silver birch measured in the study except diameter growth were significantly affected by the growth media (Tab. 8). The highest seedling height value was recorded in FP70P10Z20 $(20.73 \mathrm{~cm})$, and no treatment differences in seedling height were obtained for those grown in pure peat and FP90Z10. Diameter did not differ significantly with growing media types.

In all the substrates, the lowest root dry weight, shoot dry weight and the DQI were recorded in growth media made of peat $(80 \%)$, perlit (10\%) and zeolite $(10 \%)$, and no treatment differences in DQI were obtained for those grown in other media. SQ was the highest in P100, FP70P10Z20 and FP90Z10. The silver birch seedlings growth in pure peat or in medium of FP70P10Z20 and FP90Z10 have similar seedling morphological parameters.

Although in some plants there was no significant correlation between shoot height and seedling outplanting performance (del Campo et al., 2010; Tsakaldimi et al., 2013), other studies found better survival in some species

Tab. 7. Morphological characteristics of one-year-old of Scots pine seedlings

\begin{tabular}{cccccccc}
\hline $\begin{array}{c}\text { Growing } \\
\text { medium }\end{array}$ & $\begin{array}{c}\text { Height } \\
(\mathrm{cm})\end{array}$ & $\begin{array}{c}\text { Diameter } \\
(\mathrm{mm})\end{array}$ & $\begin{array}{c}\text { Root } \\
(\mathrm{g} \mathrm{DM})\end{array}$ & $\begin{array}{c}\text { Shoot } \\
(\mathrm{g} \mathrm{DM})\end{array}$ & SQ & S/R & DQI \\
\hline FP100 & $13.52^{\mathrm{a}}$ & 3.40 & $1.31^{\mathrm{a}}$ & $1.79^{\mathrm{a}}$ & $3.98^{\mathrm{a}}$ & $1.36^{\mathrm{b}}$ & $0.58^{\mathrm{a}}$ \\
FP70P20Z10 & $13.03^{\mathrm{ab}}$ & 3.55 & $1.02^{\mathrm{c}}$ & $1.59^{\mathrm{abc}}$ & $3.67^{\mathrm{b}}$ & $1.55^{\mathrm{a}}$ & $0.50^{\mathrm{b}}$ \\
FP70P10Z20 & $12.45^{\mathrm{bc}}$ & 3.53 & $1.17^{\mathrm{bc}}$ & $1.53^{\mathrm{bc}}$ & $3.53^{\mathrm{c}}$ & $1.31^{\mathrm{b}}$ & $0.57^{\mathrm{a}}$
\end{tabular}

Means within each column followed by the same letter are not significantly different $(\mathrm{p}<0.05)$; $D M=$ dry matter; $S Q=S$ turdiness quotient; $S / R=S h o o t$ root ratio DQI=Dickson's Quality Index

Tab. 8. Morphological characteristics of one-year-old of silver birch seedlings

\begin{tabular}{|c|c|c|c|c|c|c|c|}
\hline $\begin{array}{l}\text { Growing } \\
\text { medium }\end{array}$ & $\begin{array}{l}\text { Height } \\
(\mathrm{cm})\end{array}$ & $\begin{array}{c}\text { Diameter } \\
(\mathrm{mm})\end{array}$ & $\begin{array}{c}\text { Root } \\
\text { (g DM) }\end{array}$ & $\begin{array}{l}\text { Shoot } \\
(\text { g DM) }\end{array}$ & SQ & $S / R$ & DQI \\
\hline FP 100 & $19.59 \mathrm{ab}$ & 5.03 & $0.93 a$ & $0.83 \mathrm{ab}$ & $3.89 a$ & $0.89 \mathrm{ab}$ & $0.37 \mathrm{a}$ \\
\hline FP70P20Z10 & $17.91 \mathrm{bc}$ & 4.87 & $0.89 a$ & $0.74 \mathrm{ab}$ & $3.68 \mathrm{~b}$ & $0.83 b$ & $0.36 \mathrm{a}$ \\
\hline FP70P10Z20 & $20.73 a$ & 5.05 & $1.00 \mathrm{a}$ & $0.90 \mathrm{a}$ & $4.10 \mathrm{a}$ & $0.90 \mathrm{ab}$ & $0.38 \mathrm{a}$ \\
\hline FP90Z10 & $19.71 \mathrm{ab}$ & 4.94 & $0.90 \mathrm{a}$ & $0.81 \mathrm{ab}$ & $3.98 \mathrm{a}$ & $0.91 \mathrm{ab}$ & $0.35 \mathrm{a}$ \\
\hline FP80Z20 & $18.53 \mathrm{bc}$ & 4.91 & $0.86 \mathrm{ab}$ & $0.81 \mathrm{ab}$ & $3.77 \mathrm{~b}$ & $0.94 \mathrm{a}$ & $0.35 \mathrm{a}$ \\
\hline FP80P10Z10 & $17.41 \mathrm{c}$ & 4.64 & $0.71 b$ & $0.70 \mathrm{~b}$ & $3.75 b$ & $0.98 \mathrm{a}$ & $0.30 \mathrm{~b}$ \\
\hline
\end{tabular}

Means within each column followed by the same letter are not significantly different $(\mathrm{p}<0.05)$; $\mathrm{DM}=$ dry matter, $S \mathrm{Q}=$ sturdiness quotient, $\mathrm{S} / \mathrm{R}=\mathrm{Shoot}$ root ratio, DQI=Dickson's Quality Index 
569

with taller seedlings (Villar-Salvador et al., 2004; Tsakaldimi et al., 2013). As with height, diameter is not always correlated to field survival but is related to subsequent growth (Thompson, 1985). Nonetheless, root collar diameter is a good indicator of growth potential after planting for some forestry species such as Cedrus libani (Semerci, 2005).

Root-collar diameter has been recognized as an important initial attribute of nursery seedlings to promote field survival, particularly under drought conditions in previous studies (South et al., 1993 and 2001). Root collar diameter was found to be the best predictor of second-year outplanting survival in five Mediterranean species (Quercus ilex, Q. coccifera, Ceratonia siliqua, Pinus halepensis and Pistacia lentiscus) (Tsakaldimi et al., 2013). In general, larger seedlings had better field survival, and diameter was the common variable that accurately predicted survival for many species. Large diameter seedlings are likely to have more stored nutrients and carbohydrates (Tsakaldimi et al., 2013).

The present study showed that, for two studied species, seedling diameter growth did not differ significantly among the growing media.

There were no significant differences between the growing media in the diameter growth of Scots pine and silver birch seedlings. Although the tallest Scots pine seedlings were grown in peat, no treatment differences were obtained for those grown in peat, FP70P20Z10 and FP90Z10. The highest shoot height of silver birch was recorded in FP70P10Z20, the the seedling growth in pure growing media or in the media of FP70P10Z20 and FP90Z10 have similar seedling morphological parameters. This suggests a good potential for seedling performance in the field. Ayan and Tufekcioglu (1996) found that zeolite as a growing media had no positive effects on morphology of Scots pine seedlings. Seedlings grown in the peat-based media with $10 \%$ zeolite or without zeolite did not differ significantly in oriental spruce seedlings (Ayan and Tilki, 2007).

Total seedling dry weight and Dickson's quality index was found to be very important in predicting second-year field survival for Pinus halepensis and Pistacia lentiscus (Tsakaldimi et al., 2013). DQI indicates plant potential for field survival and growth with performance increasing as DQI values rise in previous studies (Oliet, 2000; Bayala et al., 2009; Manas et al., 2009). In the present study, in general, DQI of Scots pine and silver birch seedlings was high in peat and peat mixtures containing zeolit.

The height/diameter index can serve as a simple index to predict outplanting survival and it could accurately predict seedling outplanting survival in some tree species (Thompson, 1985; Villar-Salvador et al., 2004; Manas et al., 2009; Tsakaldimi et al., 2013). In the present study SQ was the highest in pure media in Scots pine, and it did not differ significantly with the growing media of peat, FP70P10Z20 and FP90Z10 in silver birch.

Addition of perlite and fine quartz sand to peat medium did not affect seedling growth negatively but affected rooting slightly in Scots pine and silver birch (Heiskanen and Rikala, 1998). Rooting of Norway spruce and silver birch was greater in pure peat medium than peat mixtures containing perlite and/or fine sand. No clear benefit for seedling rooting and establishment after planting was found by incorporating fine or coarse constituents in proportions below $50 \%$ into peat container medium (Heiskanen and Rikala, 2000).

Tab. 9. Pearson correlation coefficients ${ }^{*}$ among growing media properties and Scots pine seedling attributes

\begin{tabular}{|c|c|c|c|c|c|c|c|}
\hline $\begin{array}{c}\text { Media } \\
\text { properties }\end{array}$ & $\begin{array}{l}\text { Height } \\
(\mathrm{cm})\end{array}$ & $\begin{array}{c}\text { Diameter } \\
(\mathrm{mm})\end{array}$ & $\begin{array}{l}\text { Root } \\
(\text { g DM) }\end{array}$ & $\begin{array}{l}\text { Shoot } \\
\text { (g DM) }\end{array}$ & $\mathrm{H} / \mathrm{D}$ & DQI & $S / R$ \\
\hline $\mathrm{pH}$ & $-0,24$ & 0,12 & 0,06 & 0,02 & $-0,46^{*}$ & 0,24 & $-0,45^{*}$ \\
\hline EC & 0,07 & 0,26 & 0,07 & $-0,04$ & $-0,07$ & 0,17 & $-0,14$ \\
\hline Water holding cap. & 0,40 & 0,32 & 0,14 & 0,05 & 0,39 & 0,12 & 0,17 \\
\hline Air cap. & $-0,57^{*}$ & $-0,22$ & $-0,13$ & $-0,44$ & $-0,73^{*}$ & $-0,01$ & $-0,60^{*}$ \\
\hline Total Por. & 0,05 & 0,22 & 0,06 & $-0,09$ & $-0,07$ & 0,13 & $-0,24$ \\
\hline CEC & 0,05 & 0,02 & $-0,12$ & $-0,28$ & 0,07 & $-0,12$ & 0,05 \\
\hline $\mathrm{C} / \mathrm{N}$ & $-0,24$ & $-0,61^{*}$ & $-0,43^{*}$ & $-0,36$ & 0,04 & $-0,56^{*}$ & 0,39 \\
\hline O.M. \% & 0,18 & 0,32 & 0,13 & $-0,01$ & 0,06 & 0,18 & $-0,13$ \\
\hline Na ppm & $-0,49^{*}$ & $-0,43^{*}$ & $-0,19$ & $-0,28$ & $-0,46^{*}$ & $-0,16$ & $-0,37$ \\
\hline $\mathrm{K}$ ppm & $0,42^{*}$ & 0,36 & 0,31 & $0,56^{*}$ & 0,40 & 0,29 & 0,34 \\
\hline $\mathrm{Mg} \mathrm{ppm}$ & $-0,28$ & $-0,52^{*}$ & $-0,35$ & $-0,23$ & $-0,08$ & $-0,44^{*}$ & 0,34 \\
\hline P ppm & 0,01 & $-0,26$ & 0,04 & $-0,08$ & $0,45^{*}$ & $-0,32$ & $-0,74^{*}$ \\
\hline $\mathrm{B}$ ppm & $-0,27$ & $-0,26$ & $-0,33$ & $-0,26$ & $-0,24$ & $-0,33$ & 0,40 \\
\hline C \% & 0,11 & 0,25 & 0,04 & $-0,09$ & 0,01 & 0,09 & $-0,06$ \\
\hline N \% & 0,12 & 0,27 & 0,06 & $-0,08$ & 0,01 & 0,11 & $-0,07$ \\
\hline $\mathrm{Zn} \mathrm{ppm}$ & 0,37 & 0,19 & 0,01 & $-0,13$ & $0,45^{*}$ & $-0,06$ & 0,36 \\
\hline $\mathrm{Cu}$ ppm & 0,02 & $-0,14$ & $-0,26$ & $-0,23$ & 0,13 & $-0,32$ & $0,73^{*}$ \\
\hline $\mathrm{Al} \mathrm{ppm}$ & $-0,14$ & $-0,38$ & $-0,25$ & $-0,10$ & 0,04 & $-0,34$ & 0,42 \\
\hline Ca ppm & 0,02 & $-0,29$ & $-0,11$ & $-0,04$ & 0,24 & $-0,26$ & 0,23 \\
\hline $\mathrm{Fe}$ ppm & 0,08 & $-0,19$ & $-0,01$ & 0,11 & 0,26 & $-0,13$ & 0,23 \\
\hline Mn ppm & 0,39 & $0,47^{*}$ & 0,30 & 0,19 & 0,27 & 0,33 & $-0,14$ \\
\hline $\mathrm{Pb} \mathrm{ppm}$ & 0,38 & $0,44^{*}$ & 0,28 & 0,13 & 0,28 & 0,29 & $-0,17$ \\
\hline S ppm & 0,24 & 0,33 & 0,15 & 0,01 & 0,14 & 0,19 & $-0,12$ \\
\hline
\end{tabular}

${ }^{*}$ Significant at $\mathrm{p}<0.05$ 
Tab. 10. Pearson correlation coefficients ${ }^{*}$ among growing media properties and silver birch seedling attributes

\begin{tabular}{cccccccc}
\hline $\begin{array}{c}\text { Media } \\
\text { properties }\end{array}$ & $\begin{array}{c}\text { Height } \\
(\mathrm{cm})\end{array}$ & $\begin{array}{c}\text { Diameter } \\
(\mathrm{mm})\end{array}$ & $\begin{array}{c}\text { Root } \\
(\mathrm{g} \mathrm{DM})\end{array}$ & $\begin{array}{c}\text { Shoot } \\
(\mathrm{g} \mathrm{DM})\end{array}$ & H/D & DQI & S/R \\
\hline pH & $-0,24$ & 0,12 & 0,06 & 0,02 & $-0,46^{*}$ & 0,24 & $-0,45^{*}$ \\
EC & 0,07 & 0,26 & 0,07 & $-0,04$ & $-0,07$ & 0,17 & $-0,14$ \\
Water holding cap. & 0,40 & 0,32 & 0,14 & 0,05 & 0,39 & 0,12 & 0,17 \\
\hline Air cap. & $-0,57^{*}$ & $-0,22$ & $-0,13$ & $-0,44$ & $-0,73^{*}$ & $-0,01$ & $-0,60^{*}$ \\
Total Por. & 0,05 & 0,22 & 0,06 & $-0,09$ & $-0,07$ & 0,13 & $-0,24$ \\
\hline CEC & 0,05 & 0,02 & $-0,12$ & $-0,28$ & 0,07 & $-0,12$ & 0,05 \\
C/N & $-0,24$ & $-0,61^{*}$ & $-0,43^{*}$ & $-0,36$ & 0,04 & $-0,56^{*}$ & 0,39 \\
\hline O.M. $\%$ & 0,18 & 0,32 & 0,13 & $-0,01$ & 0,06 & 0,18 & $-0,13$ \\
Na ppm & $-0,49^{*}$ & $-0,43^{*}$ & $-0,19$ & $-0,28$ & $-0,46^{*}$ & $-0,16$ & $-0,37$ \\
\hline K ppm & $0,42^{*}$ & 0,36 & 0,31 & $0,56 *$ & 0,40 & 0,29 & 0,34 \\
Mg ppm & $-0,28$ & $-0,52^{*}$ & $-0,35$ & $-0,23$ & $-0,08$ & $-0,44^{*}$ & 0,34 \\
\hline P ppm & 0,01 & $-0,26$ & 0,04 & $-0,08$ & $0,45^{*}$ & $-0,32$ & $-0,74^{*}$ \\
B ppm & $-0,27$ & $-0,26$ & $-0,33$ & $-0,26$ & $-0,24$ & $-0,33$ & 0,40 \\
C \% & 0,11 & 0,25 & 0,04 & $-0,09$ & 0,01 & 0,09 & $-0,06$ \\
N \% & 0,12 & 0,27 & 0,06 & $-0,08$ & 0,01 & 0,11 & $-0,07$ \\
\hline Zn ppm & 0,37 & 0,19 & 0,01 & $-0,13$ & $0,45^{*}$ & $-0,06$ & 0,36 \\
Cu ppm & 0,02 & $-0,14$ & $-0,26$ & $-0,23$ & 0,13 & $-0,32$ & $0,73^{*}$ \\
\hline Al ppm & $-0,14$ & $-0,38$ & $-0,25$ & $-0,10$ & 0,04 & $-0,34$ & 0,42 \\
Ca ppm & 0,02 & $-0,29$ & $-0,11$ & $-0,04$ & 0,24 & $-0,26$ & 0,23 \\
\hline Fe ppm & 0,08 & $-0,19$ & $-0,01$ & 0,11 & 0,26 & $-0,13$ & 0,23 \\
\hline Mn ppm & 0,39 & $0,47^{*}$ & 0,30 & 0,19 & 0,27 & 0,33 & $-0,14$ \\
\hline Pb ppm & 0,38 & $0,44^{*}$ & 0,28 & 0,13 & 0,28 & 0,29 & $-0,17$ \\
\hline S ppm & 0,24 & 0,33 & 0,15 & 0,01 & 0,14 & 0,19 & $-0,12$ \\
\hline
\end{tabular}

${ }^{*}$ Significant at $\mathrm{p}<0.05$

In the present study, growing media properties affected some seedling attributes (Tab. 9). Height of Scots pine seedlings had a significant positive correlation with $\mathrm{pH}, \mathrm{Ec}$, water holding capacity, total porosity, organic matter, CEC, $\mathrm{S}$ and $\mathrm{Mn}$. Seedling diameter was significantly affected by $\mathrm{Ec}$, water holding capacity, $\mathrm{Na}, \mathrm{Ca}$ and $\mathrm{Fe}$ of the growing media. Increasing in $\mathrm{K}$ content in the growing media with $20 \%$ zeolite decreased height growth of Scots pine. These results concur with those of Ayan and Tufekcioglu (2006) that there is a negative correlation between seedling height of Scots pine and K content of growing medium (peat, tea residue compost, perlite, fine pumice, coarse pumice, river sand, and zeolite).

Root dry weight, shoot dry weight, H/D, DQI and S/R were also significantly affected by the growing media. Most growing media properties (EC, water holding capacity, total porosity, CEC, OM, P, N, Zn, Fe, Mn, S) affected stem dry weight, and positive correlation with total porosity could be an indication of poor aeration in the growing medium due to irrigation during summer in seedling nursery.

Seedling height of silver birch negatively correlated with $\mathrm{Na}$ of growing media but positively correlated with water holding capacity (Tab. 10). Seedling diameter was negatively correlated with $\mathrm{C} / \mathrm{N}$ and $\mathrm{Mg}$ but positively correlated with $\mathrm{Mn}$, and DQI was negatively affected by $\mathrm{C} / \mathrm{N}$ and $\mathrm{Mg}$ of the growing media.

\section{Conclusions}

Based on the results of the study, it can be concluded that, on average, the seedlings grew best in pure peat, but in proportions of $10 \%$ in peat, zeolite additive used was shown to be a feasible material for Scots pine seedling growing. The results also indicated that zeolit could be used at up to $20 \%$ by volume in silver birch with no negative effects on plant growth. The results suggest that zeolite has potential to be used as a component of peat-based growing medium. Although seedlings may have good morphological attributes that include physical parameters, it does not necessarily imply good survival and productivity in the field after planting. Thus, more research is needed into the management of zeolite additive growing media during nursery cultivation and to evaluate of seedlings grown in such a medium with respect to field performance.

\section{Acknowledgements}

We would like to thank to Dr. Adil Aydin and Dr. Mehmet Guven for invaluable support. We also thank the staff of the Erzurum Forest Nursery for their help, and the soil laboratory of the East Anatolian Forest Research Institute and Soil Science Department of Ataturk University for the soil analyses. This article includes most parts of the master thesis of the first author.

\section{References}

Aldrete A, Mexal JG (2005). Sowing depth, media, and seed size interact to influence emergence of three pine species. Tree Planters' Notes 51(1):27-31.

Aphalo P, Rikala R (2003). Field performance of silver-birch planting-stock grown at different spacing and in containers of different volume. New Forests 25:93-108.

Ayan S (2002). Using of zeolite mineral for seedling production and afforestration practices. Gazi Univ J For Fac 2(1):78-88. 
571

Ayan S, Tufekcioglu A (2006). Growth responses of Scots pine seedlings grown in peat-based media amended with natural zeolite. J Environ Biol 27(1):27-34.

Ayan S, Tilki F (2007). Morphological attributes of oriental spruce [Picea orientalis (L.) Link.] seedlings grown in peatbased media amended with natural zeolite. Acta Agron Hung 55(3):363-373.

Aytas V, Tilki F (2012). Effects of seedling type and planting time on Scots pine field performance in Erzurum-Tortum, Turkey. Artvin Coruh Univ J For Fac 13(1):13-24.

Bayala J, Dianda ZM, Wilson ZJ, Ouedraogo SJ, Sanon ZK (2009). Predicting field performance of five irrigated tree species using seedling quality assessment in Burkina Faso, West Africa. New Forests 38:309-322.

Bunt AC (1988). Media and mixes of container-growth plants. Unwin Hyman, Boston.

Chong C, Lumis GP (2002). Mixtures of paper mill sludge, wood chips, bark and peat in substrates for pot-in-pot shade tree production. Can J Plant Sci 80(3):669-675.

Del Campo AD, Navarro RM, Ceacero CJ (2010) Seedling quality and field performance of commercial stocklots of containerized holm oak (Quercus ilex) in Mediterranean Spain: an approach for establishing a quality standard. New Forests 39:19-37.

Dey DC, Parker WC (1997). Morphological indicators of stock quality and field performance of red oak (Quercus rubra L.) seedlings underplanted in a central Ontario shelterwood. New Forests 14:145-156.

Dierauf TA, Garner JW (1996). Effect of initial root collar diameter on survival and growth of yellow poplar seedlings over 17 years. Tree Planters' Notes 47(1):30-33.

Duryea ML (1985). Evaluating seedling quality: principles, procedures, and predictive abilities of major tests. Oregon State University Portland, Oregon.

Flint A, Flint LE (2002). Particle density, p. 229-240. In: Dick WA (Ed.). Laboratory Methods. Methods of Soil Analysis. Part 4-Physical Methods. SSA Book Series: 5. SSSA. Inc., Madison, WI.

Grossman RB, Reinsch TG (2002). The solid phase. Bulk density and linear extensibility, p. 201-228. In: Dick WA (Ed.). Methods of soil analysis. part 4-Physical methods. SSA Book Series: 5, SSSA. Inc. Madison, WI.

Heiskanen J (1993). Favourable water and aeration conditions for growth media used in containerized tree seedling production: A review. Scand J For Res 8:337-358.

Heiskanen J (1997). Air-filled porosity of eight growth media based on sphagnum peat during drying from container capacity. Acta Hort 450:277-286.

Heiskanen J (2013). Effects of compost additive in sphagnum peat growing medium on Norway spruce container seedlings. New Forests 44:101-118.

Heiskanen J, Rikala R (1998). Influence of different nursery container media on rooting of Scots pine and silver birch seedling after transplanting. New Forests 16:27-42.

Heiskanen J, Rikala R (2000). Effect of peat-based container media on establishment of Scots pine, Norway spruce and silver birch seedlings after transplanting in contrasting water conditions. Scand J For Res 15:49-57.

Jacobs DF, Goodman RC, Gardiner ES, Salifu KF, Overton RP, Hernandez G (2012). Nursery stock quality as an indicator of bottomland hardwood forest restoration success in the Lower Mississippi River Alluvial Valley. Scan J For Res 27:255-269.

Jacobs DF, Ross-Davis AL, Davis AS (2004). Establishment success of conservation tree plantations in relation to silvicultural practices in Indiana, USA. New Forests 28:23-36.

Jaenicke H (1999). Good Tree Nursery Practices. Practical guidelines for research nurseries. World Agroforestry Centre (ICRAF), Nairobi, Kenya.

Kacar B (1996). Soil Analyses. AU Ziraat Fakultesi Egitim Araştırma ve Gelistirme Vakfi, No: 3. Ankara.

Kalra YP, Maynard DG (1991). Methods manual for forest soil and plant analysis. Forestry Canada, Northwest Region Information Report, NOR-X-319, Canada.

Koksaldi V (1999). Agricultural and nursery use potentials of Gordes and Yenikent Zeolites. MSc Thesis. Ankara Univ. Publ, Ankara, Turkey.

Landis T D, Tinus RW, McDonald SE, Barnett JP (1990). Containers and Growth Media. The Container Tree Nursery Manual. Vol. 2. USDA Forest Service, Washington DC. Agric Handbook 674-87.

Langerud BR, Sandvik M (1987). Development of containerized Picea abies (L.) Karst. seedlings grown with heavy watering on various peat, perlite and mineral wool mixtures. New Forests 1:89-99.

Li GL, Liu Y, Zhu Y, Yang J, Sun HY, Jia ZK, Ma LY (2011). Influence of initial age and size on the field performance of Larix olgensis seedlings. New Forest 42:215-226.

Manas P, Castro E, De las Heras J (2009). Quality of maritime pine (Pinus pinaster Ait.) seedlings using waste materials as nursery growing media. New Forests 37:295-311.

Markovich A, Takac A, Illin Z, Ito T, Tognoni F (1995). Enriched zeolites as substrate component in the production of pepper and tomato seedling. Acta Hort 396:321-328.

Mattsson A (1997). Predicting field performance using seedling quality assessment. New Forests 23:227-252.

Mexal JG, Landis TD (1990). Target seedling concepts: height and diameter target seedling symposium. Proceedings, combined meeting of western forest nursery associations, $\mathrm{p}$. 17-35. August 13-17, 1990, USDA For Serv GTR-RM-200, Roseburg, OR.

Nelson DW, Sommers LE (1996). Total carbon, organic carbon, and organic matter, p. 961-1010. In: Sparks DL et al. (Eds.). Methods of Soil Analysis. Soil Sci Soc America, Madison. WI.

Oliet J (2000). La calidad de la postura forestal en vivero. Escuela Tecnica Superior de Ingenieros Agronomos y de Montes de Cordoba. Universidad de Cordoba, Cordoba. 
Pickering HW, Menzies NW, Hunter MN (2002). Zeolite/rock phosphate-a novel slow release phosphorus fertiliser for potted plant production. Sci Hortic 94:333-343.

Pinto JR, Marshall JD, Dumroese RK, Davis AS, Douglas R, Cobos DR (2011). Establishment and growth of container seedlings for reforestation: A function of stocktype and edaphic conditions. For Ecol Manag 261:1876-1884.

Richard WT, McDonald SE (1979). How to grow tree seedlings in containers in greenhouses. North Dakota, USA.

Schmilewski G (1992). The possibilities and limits of substituting peat in growing media and for soil improvement, pp. 369-381. In: Proc. 9th Int. Peat Congress. Uppsala, Sweden, June, 2226, International Peat Society, Jyuaskyla, Finland.

Semerci A (2005). Fifth year performance of morphologically graded Cedrus libani sedling in the Central Anatolia region of Turkey. Turk J Agric For 29:483-491.

South DB, Haris SW, Barnett JP, Hainds MJ, Gjerstad DH (2005). Effect of container type and seedling size on survival and early height growth of Pinus palustris seedlings in Alabama, U.S.A. For Ecol Manag 204:385-398.

South DB, Rakestraw JL, Lowerts GA (2001). Early gains from planting large diameter seedlings and intensive management are additive for loblolly pine. New Forests 22:97-110.

South DB, Zwolinski JB, Donald DGM (1993). Interactions among seedling diameter grade, weed control and soil cultivation for Pinus radiata in South Africa. Can J For Res 23:2078-2082.
Stone EC, Cavallaro JI, Norberg EA (2003). Critical RGCexpected survival models for predicting survival of planted white fir (Abies concolor Lindl.) seedlings. New Forests 26:6582.

Thompson BE (1985). Seedling morphological evaluation-what you can tell by looking, p. 59-71. In: Duryea ML (Ed.). Forest Research Lab. Oregon State Univ, Corvallis, OR.

Tsakaldimi M, Ganatsas P, Jacobs DF (2013). Prediction of planted seedling survival of five Mediterranean species based on initial seedling morphology. New Forests 44:327-339.

Tsakaldimi M, Tsitsoni T, Ganatsas G, Zagas T (2009). A comparison of root architecture and shoot morphology between natural regenerated and container seedlings of Quercus ilex L. Plant Soil 324:103-113.

Villar-Salvador P, Planelles R, Enriquez E, Penuelas-Rubira J (2004). Nursery cultivation regimes, plant functional attributes and field performance relationships in the Mediterranean oak Quercus ilex L. For Ecol Manag 196:257266.

Ward JS, Gent MPN, Stephens GR (2000). Effects of planting stock quality and browse protection-type on height growth of northern red oak and eastern white pine. For Ecol Manag 127:205-216.

Wilson BC, Jacobs DF (2006). Quality assessment of temperate zone deciduous hardwood seedlings. New Forests 31:417-433. 